ROCZNIKI PEDAGOGICZNE

Tom 12(48), numer 2 - 2020

DOI: http://dx.doi.org/10.18290/rped20122-9

KAROL MOTYL

\title{
STRUKTURALIZACJA CZASU UCZNIÓW LICEUM W FIZYCZNEJ PRZESTRZENI SZKOŁY
}

\section{WPROWADZENIE}

Wychowanie i nauczanie dokonują się zawsze w określonym kontekście, który jest szczególnie ważny dla edukacji młodego pokolenia. Obserwując przyspieszenie przemian, jakim podlega współczesny świat a wraz z nim człowiek, można dojść do wniosku, że czas i przestrzeń stanowią układ odniesienia dla współczesnych stosunków społecznych (Pawełczyńska, 1986, s. 145). Przyglądając się życiu społecznemu, warto odnieść się przede wszystkim do pojęcia czasu ze szczególnym uwzględnieniem nowych sposobów konceptualizacji temporalnego wymiaru relacji interpersonalnych (Adam, 2010, s. 64-85).

Szkoła, jako jedna z instytucji edukacyjnych, z uwzględnieniem swojej wielowymiarowości, może być analizowana z różnych perspektyw poprzez odsłanianie poszczególnych warstw w celu dotarcia do źródeł jej obecnego kształtu. Sam budynek szkoły może być potraktowany jako arena ujawniania się nie tylko różnych funkcji szkoły, ale także przejawów realizowania tychże funkcji. Będą się one manifestować m.in. w relacjach interpersonalnych panujących w tej instytucji (Nalaskowski, 2002, s. 7-9). Toteż sposób, w jaki uczniowie wykorzystują czas podczas swojego pobytu w szkole, wydaje się być jednym z istotnych aspektów dla pedagogiki. Temporalny wymiar życia szkoły w odniesieniu do tychże relacji stał się więc przedmiotem przeprowadzonych analiz, natomiast celem tekstu jest charakterystyka poszczególnych przestrzeni szkoły w kontekście przejawianych przez uczniów form strukturalizacji czasu.

Dr Karol Motyl - Katedra Pedagogiki, Wydział Nauk Społecznych Uniwersytetu Humanistyczno-Przyrodniczego im. Jana Długosza w Częstochowie; e-mail: k.motyl@ujd.edu.pl; ORCID: https://orcid.org/0000-0003-4203-6434. 


\section{KATEGORIA CZASU W BADANIACH PEDAGOGICZNYCH}

Według Henryki Kwiatkowskiej czas jest jedną z zaniedbanych kategorii w naukach pedagogicznych (2001, s. 57). Podobnie uważa Jarosław Jagieła, pisząc, że ,pedagogika [...] stawia pierwsze kroki w odniesieniu do problematyki czasu" (Jagieła, Sarnat-Ciastko, 2015, s. 76). Agata Przybysz, przeszukując polskie zasoby leksykalne pedagogiki, odnalazła dwa hasła związane z czasem: czas reakcji i czas wolny (2010, s. 150), choć występują także badania nad czasem $w$ formie biografii oraz nad orientacjami temporalnymi. W rozważaniach nad edukacją istnieje także kategoria budżetu czasu, którą można określić jako zestawienie odcinków czasu przewidzianych na realizację różnych czynności życiowych. Warto zaznaczyć, że problematyka zarządzania czasem w szkole w ramach jego budżetu stała się obecna w badaniach Zbigniewa Kwiecińskiego. Przyjrzał się on strukturze wykorzystania czasu poszczególnych lekcji, wyodrębniając czas sprzyjający rozwojowi ucznia, czas zorganizowany (nieszkodliwy dla ucznia) oraz czas stracony dla ucznia (2014, s. 241-242).

Wykorzystanie czasu w szkole bada także Ireneusz Kawecki. Pisze on, że zarówno potoczna obserwacja życia klas szkolnych, jak i badania empiryczne pokazują istotne znaczenie czasu w kształceniu. Analizy wykazały, że uczniowie tych nauczycieli, którzy efektywniej dysponują posiadanym czasem lekcyjnym, uczą się więcej w porównaniu z uczniami nauczycieli niewykazujących takiej dbałości o czas (2003, s. 65-68). W tym aspekcie należy dostrzec, że ważniejsze jest to, co nauczyciel i uczniowie robią w czasie, który mają do dyspozycji, niż fizyczna ilość czasu (Pankowska, Sokołowska-Dzioba, 2015, s. 65-69). Ciekawie na tym tle prezentują się badania Renaty Wawrzyniak-Beszterdy, która analizowała doświadczenia komunikacyjne licealistów w czasie lekcji. Wyniki pokazują, że prawie $60 \%$ uczniów nigdy nie miało lub miało bardzo rzadko poczucie prawa do dysponowania czasem rozmowy podczas lekcji (2002, s. 72). Warto również wspomnieć, że badania z zakresu temporalnego wymiaru edukacji prowadzi m.in. Alicja Korzeniecka-Bondar, która wykorzystuje czas jako kategorię demaskującą np. pozór w szkole i podporządkowanie szkolnej codzienności (2011, s. 113).

Wydaje się, że badacze edukacji mogą nie dostrzegać całego potencjału czasu jako kategorii analitycznej. Na podstawie lektury podejść teoretycznych do tego fenomenu można wywnioskować, że czas reakcji i czas wolny stanowią tylko mały ułamek możliwości eksploracyjnych, jakie na gruncie pedagogiki dostarcza analiza pojęcia czasu. Omawiana kategoria zdaje się 
być jedną z ważniejszych w pedagogice, ponieważ wszystkie zdarzenia edukacyjne dzieją się w czasie. Czas je porządkuje, określa długość, szybkość, okres trwania zdarzeń oraz odstępy między nimi. Jednak czas w szkole nie jest tylko pewną skalą pomiaru zdarzeń i procesów czy pewną ramą odniesienia. Jest on przede wszystkim immanentną właściwością zdarzeń i procesów społecznych, gdyż - zawarty w zdarzeniach - ma określone indywidualnie znaczenie i sens (Truszkowska-Wojtkowiak, 2012, s. 252).

\section{ANALIZA TRANSAKCYJNA JAKO KONCEPCYJNY FUNDAMENT BADAŃ}

Jadwiga Staniszkis pisze o potrzebie ontologizacji czasu, czyli traktowania tego fenomenu jako elementu bytu. Badaczka wnosi o przyjęcie nowej definicji czasu, konsekwencją czego byłoby uznanie, że różne obszary ludzkiej aktywności rządzą się odmiennymi formami temporalnej strukturyzacji zjawisk występujących w ich granicach (2004, s. 48-50). Powyższy postulat został zrealizowany w analizie transakcyjnej, a jego odzwierciedlenie można odnaleźć w koncepcji strukturalizacji czasu. Analiza transakcyjna (AT) to koncepcja osobowości i systematycznej psychoterapii służąca osobistemu rozwojowi i zmianie (Jagieła, 2012b, s. 24). Opiera się ona przede wszystkim na spójnej koncepcji psychologicznej, będącej podstawą oddziaływań terapeutycznych autorstwa Erica Berne'a, amerykańskiego psychiatry i psychoterapeuty (Pankowska, 2012, s. 13). Według Berne'a celem AT staje się stworzenie jak najbardziej otwartej i możliwie autentycznej komunikacji między emocjonalnymi i intelektualnymi strukturami osobowości ludzkiej. Zatem analiza transakcyjna przypisuje sobie zasługę wykrycia oraz stawia cel dalszego wykrywania niektórych z praw i regularności funkcjonowania ludzkiej psychiki (Harris, 2009, s. 36). Aby to osiągnąć AT jest podzielona na cztery komplementarne obszary i obejmuje: analizę struktury osobowości, analizę strukturalizacji czasu, analizę transakcji oraz analizę skryptu (Jagieła, 2012a, s. 13; Jagieła, 2001, s. 84). Drugie z wymienionych pól badawczych wykorzystane zostało w badaniach, które stanowią podstawę niniejszego tekstu.

W analizie transakcyjnej czas jest połączony $\mathrm{z}$ relacjami interpersonalnymi, gdyż tym, co pozwala zaspokoić istotne potrzeby człowieka, jest kontakt z innymi ludźmi. Stąd też każdy człowiek wypełnia swoje życie relacjami z otoczeniem społecznym. Może to być kontakt fizyczny, np. dotyk, 
może również przybierać charakter symboliczny, wyrażony słowem, gestem, spojrzeniem lub innym działaniem. Takie rzeczywiste bądź symboliczne działania dają człowiekowi pewność, że jest dostrzegany przez innych (James, Jongewart, 1994, s. 72-75). Akt uznania obecności i bycia zauważonym przez innych ludzi (Jagieła, 2012a, s. 27-29; Jagieła, 2012b, s. 210) cechuje się różną intensywnością w strukturalizacji czasu, dlatego w zależności od rodzaju i jakości interakcji międzyludzkich (Pankowska, 2001, s. 62-63; Cowles-Boyd, Boyd, 1980, s. 5-7; Mokrzycka, 2015, s. 89-99) można wyróżnić siedem sposobów strukturalizowania czasu:

- wycofanie - jest skrajnym, granicznym przypadkiem, w którym ludzie jawnie się nie komunikują; polega ono na izolacji poprzez fizyczne odejście bądź poprzez wyłączenie się psychiczne i pozostawanie ze swoimi myślami (Berne, 2008, s. 42; James, Jongeward, 1994, s. 88-89; Harris, 2009, s. 166);

- rytuały - najbezpieczniejszy rodzaj zachowań społecznych, które są mniej lub bardziej formalnymi, stylizowanymi sposobami komunikowania się, mogącymi przerodzić się $\mathrm{w}$ ceremonie o przewidywalnym przebiegu (Berne, 2008, s. 42; Jagieła, 2012a, s. 22; Jagieła, 2012b, s. 187); przybierają formę relacji prostych i stereotypowych, zapewniających dobre funkcjonowanie w towarzystwie (James, Jongeward, 1994, s. 89-90): to bezpieczna forma strukturyzacji czasu, gdyż nie wymaga wchodzenia w żadne związki lub podejmowania zobowiązań wobec innych ludzi (Harris, 2009, s. 166167; Jagieła, 2012a, s. 22; Jagieła, 2012b, s. 187);

- rozrywki - rodzaj sondowania towarzyskiego, w którym ktoś pragnie zdobyć informacje o nowych znajomych w sposób niezobowiązujący i niezagrażający (Harris, 2009, s. 168-169); to proste relacje przejawiające się podczas rozmowy na różne błahe tematy (Rogoll, 1989, s. 52); to stosunkowo bezpieczne, a jednocześnie uprzejme rozmowy, które chętnie prowadzą zwłaszcza ci, którzy jeszcze niezbyt dobrze się znają (Rogoll, 1989, s. 52);

- prace - najbardziej powszechna, wygodna (interpersonalnie) i utylitarna forma strukturalizacji czasu, nastawiona na tworzenie planu działania w materii świata społecznego; w tym przypadku programowanie materialne jest skutkiem zetknięcia się człowieka ze zmiennością świata zewnętrznego (Berne, 2000, s. 42-43) i ma ścisły związek z realną rzeczywistością (Rogoll, 1989, s. 52);

- zabawy - stosunkowo niedawno wyodrębniona i dodana forma przez Laurę Cowles-Boyd oraz Harry'ego S. Boyd'a, definiowane są jako seria trwałych relacji (o jawnych motywach), w których występują głównie pozytywne komunikaty, a efektem są pozytywne emocje; cechuje je pełna krea- 
tywność, ekspresja i spontaniczność. Zapewniają powstawanie prawdziwych emocji, takich jak radość, oraz spontaniczności na poziomie społecznym (Cowles-Boyd, Boyd, 1980, s. 7-9; Jagieła, 2012b, s. 262). Są one także przyczyną wielu przyjemnych doznań, np. fantazjowanie, świętowanie, sport, hobby (Jagieła, 2012b, s. 262; Jagieła, 2012a, s. 23);

- gry - to seria komunikatów o ukrytych motywach prowadzących do dobrze określonego, z góry przewidzianego wyniku (Jagieła, 2012a, s. 22; Jagieła, 2012b, s. 77; Berne, 2000, s. 37-38); nie mają one nic wspólnego z pierwotnymi zabawami dziecka, są następstwem utajonych zamiarów w relacjach, które zewnętrznie wydają się być słuszne, jednakże w rzeczywistości są podporządkowane ukrytym i nieszczerym, ciągle powtarzającym się motywom (Rogoll, 1989, s. 52-53);

- intymność - najatrakcyjniejsza forma kontaktu społecznego (Berne, 2000, s. 12) i graniczny sposób strukturalizacji czasu (Berne, 2008, s. 4445), w której występuje „dawanie” i „branie” bez wzajemnego wykorzystywania (Rogoll, 1989, s. 53-54); to otwarty, uczciwy i charakteryzujący się wzajemnym, wolnym od wykorzystywania, niewymuszonym dzieleniem się (Berne, 2008, s. 44-45), empatią, czułością i poczuciem bliskości (James, Jongeward, 1994, s. 92-94) stosunek międzyludzki niewykorzystujący gier (Berne, 2008, s. 44-45) i wyrażający prawdziwe uczucia, myśli i doświadczenia zaangażowanych w niego osób.

Wydaje się, że strukturalizacja czasu w analizie transakcyjnej jest nowym sposobem temporalnej konceptualizacji relacji międzyludzkich panujących w rozmaitych instytucjach (także edukacyjnych). Jest to jedna z wielu możliwości wykorzystania potencjału zawartego w kategorii analitycznej, jaką jest właśnie czas. To on, będący osobliwym i fascynującym zjawiskiem, jest podstawowym absolutem rzeczywistości i ludzkiego poznania. Człowiek jest w nim zanurzony, a każde jego doświadczenie (indywidualne czy społeczne) jest kategoryzowane w ramach czasowych, pozwalających realizować porządek, spójność i znaczenie w sferze zdarzeń (Bańka, 2010, s. 103). Co więcej, każdy wytwór człowieka ma swój czasowy charakter, włączając w to różne instytucje społeczne, których temporalny wymiar uwidacznia się w dynamice ich funkcjonowania i relacjach międzyludzkich $w$ nich panujących. Pojęcie czasu najczęściej nie jest zwerbalizowane, a nawet uświadamiane i znajduje wyraz raczej w działaniu aniżeli w słowie, dlatego wymaga szczególnych zabiegów badawczych. Z racji swej „oczywistości”, „Zwykłości” czy „naturalnego" wbudowania w codzienność jest szczególnie trudnym i opornym przedmiotem analiz, które wymaga znalezienia właściwych per- 
spektyw teoretycznych i opracowania narzędzi badawczych czyniących tę kategorię jak najbardziej uchwytną (Tarkowska, 1992, s. 12). To może być główna trudność, którą napotykają badacze rzeczywistości społecznej rozpatrywanej przez pryzmat czasu. Kategoria ta jest natomiast bardzo pojemna i wieloaspektowa. Uwidocznia się to także w edukacji. Procesy rozwojowe, które przebiegają w środowisku wychowawczym, w relacjach wychowawczych czy w oddziaływaniach podmiotów socjalizacyjnych, dokonują się w kontekście i w obszarze swego rodzaju sprzężenia, które zawarte jest w temporalnym wymiarze, ten z kolei jest nośnikiem następującego rozwoju (Prüfer, 2016, s. 145).

\section{PROCEDURA BADAŃ WŁASNYCH}

W prezentowanym opracowaniu za przedmiot badań przyjęto formy strukturalizacji czasu uczniów tworzących klasę w liceum ogólnokształcącym w trakcie roku szkolnego. Głównym celem była natomiast charakterystyka form strukturalizacji czasu licealistów w przestrzeni szkoły. Bazując na tak postawionych przedmiocie i celu badań, sformułowany został ogólny problem badawczy: w jakich przestrzeniach szkolnych przejawiane są poszczególne formy strukturyzacji czasu uczniów?

W przeprowadzonym badaniu podstawową metodę badawczą stanowił sondaż diagnostyczny realizowany za pośrednictwem techniki mapowania (zob. A.E. Clarke, 2003; A.E. Clarke, 2005) za pośrednictwem narzędzia, które stanowiła mapa $\mathrm{w}$ formie typowego planu budynku szkoły, uczeń za pośrednictwem cyfr zaznaczał miejsca, gdzie najchętniej strukturalizuje czas w danej formie. Należy dodać, że na każdym kwestionariuszu znajdowała się legenda, w której każdej z cyfr przyporządkowany został krótki opis jednej z siedmiu form strukturalizacji czasu. Legenda została opracowana po konsultacjach z członkami Zespołu Badawczego Edukacyjnej Analizy Transakcyjnej UJD.

W badaniu wzięli udział uczniowie trzech liceów ogólnokształcących. W każdej szkole w czasie trwania roku szkolnego przeprowadzono cztery pomiary w klasach: pierwszej, drugiej i trzeciej. Badania wykonywane były $\mathrm{w}$ te same dni tygodnia w klasach w ramach lekcji, na których uczniowie (ci sami we wszystkich czterech etapach) uzupełniali (takie same w trakcie całego badania) kwestionariusze. Łącznie w badaniach zebrano 781 kwestionariuszy we wszystkich czterech etapach. 


\section{ANALIZA I INTERPRETACJA WYNIKÓW BADAŃ}

Na podstawie uzyskanych danych można określić poszczególne formy strukturalizacji czasu występujące w poszczególnych miejscach budynku liceum. Składać się one będą na transakcyjno-temporalny profil poszczególnych przestrzeni szkolnych w całym roku szkolnym. Można stwierdzić, że przód i tył budynku szkoły ma charakter typowo intymny. Czytelnia pozostaje strefą wycofania, podobnie jak toaleta. W bibliotece zauważa się rytuały, jako najczęstszą formę spędzania czasu, podobnie jak w przypadku wejścia do szkoły, sklepiku i klasy lekcyjnej. Miejscami o charakterze rozrywek są korytarz, schody i przebieralnia, natomiast szatnia ma dwojaki rytualno-rozrywkowy charakter. W sali gimnastycznej obserwuje się najwyższy wskaźnik zabaw, a prace występują głównie w pokoju nauczycielskim, sekretariacie i w gabinecie dyrektora.

Wykres 1. Graficzna interpretacja transakcyjno-temporalnego profilu przestrzeni szkoły w ciągu całego roku szkolnego $(\mathrm{N}=781$; dane w \%)

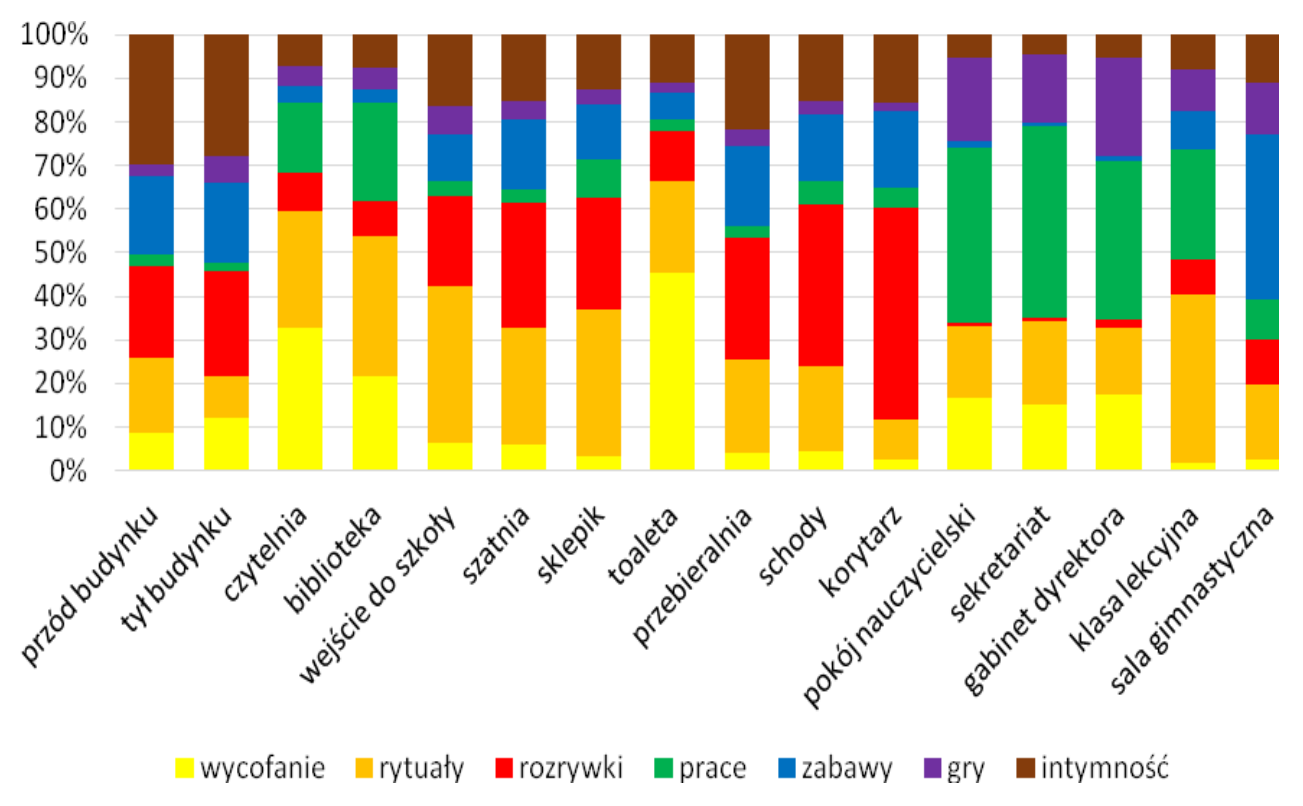

Źródło: opracowanie własne

W analizie przestrzeni szkoły pod kątem najrzadziej występujących form strukturalizacji czasu należy wskazać pokój nauczycielski, sekretariat oraz gabinet dyrektora, w którym notuje się najniższy poziom rozrywek i zabaw. 
W czytelni i bibliotece najrzadziej występują gry i zabawy, natomiast w klasie lekcyjnej i w sali gimnastycznej najmniejszy wskaźnik ma wycofanie. Sklepik, schody i korytarz są miejscami, w których prawie w ogóle nie notuje się występowania gier. Pozostałe przestrzenie (przód i tył budynku, wejście do szkoły, szatnia, toaleta i przebieralnia) mają najniższy poziom prac.

Jak wynika z powyższych analiz, intymność jest formą strukturalizacji czasu, która występuje poza murami szkoły. W samym budynku uwidocznia się strefa prac i gier (pokój nauczycielski, sekretariat i gabinet dyrektora), strefa rozrywek (korytarz, schody i przebieralnia), strefa rytuałów (klasa lekcyjna, sklepik i wejście do szkoły), strefa wycofania (czytelnia i toaleta) oraz strefa zabaw (sala gimnastyczna). Potwierdza to kolejna analiza, przeprowadzona przy wykorzystaniu jednej ze statystyk opisowych, jaką jest moda. Obliczono dominujące formy strukturalizacji czasu uczniów we wszystkich przestrzeniach szkoły w ciągu całego roku szkolnego, których wyniki ilustruje schemat 1. Można stwierdzić, że niezbędne wydaje się stworzenie w szkole miejsca przyjaznego dla intymności, ponieważ wyniki badań pokazują, że żadna przestrzeń w szkole nie sprzyja tej formie strukturalizacji czasu. Intymność natomiast jest przejawiana na zewnątrz budynku placówki.

Schemat 1. Formy strukturalizacji czasu dominujące w przestrzeniach szkoły w ciągu całego roku szkolnego $(\mathrm{N}=781)$

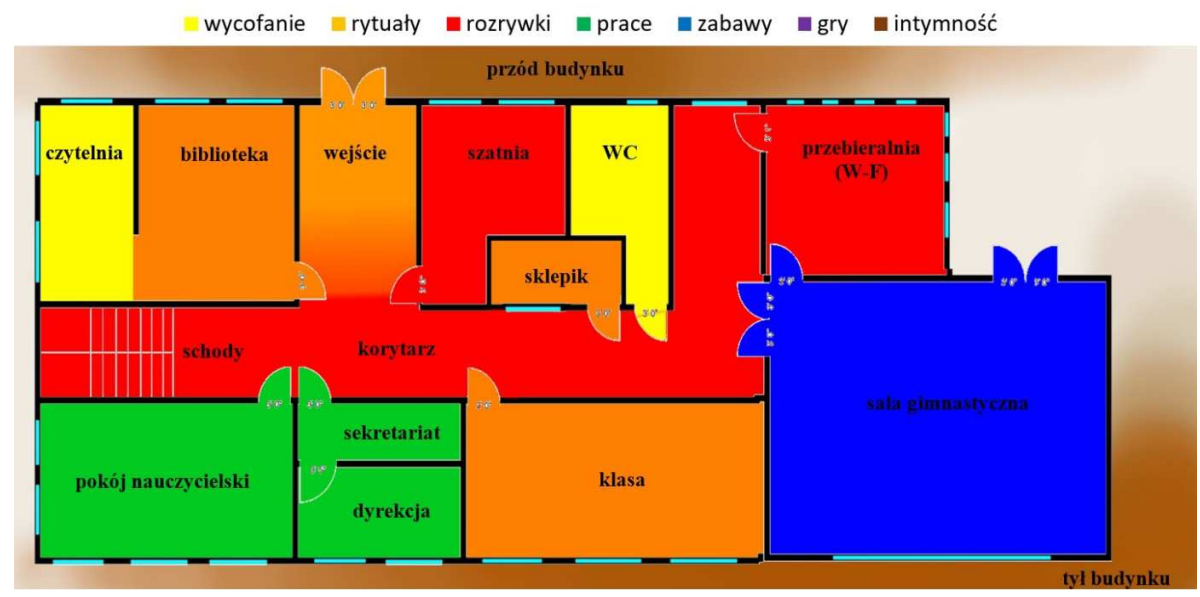

Źródło: opracowanie własne

Ponieważ badanie było wykonane czterokrotnie na tych samych respondentach, przeprowadzono analizę poszczególnych wyników testem F-Friedmana. Wykazano, że istotne statystycznie różnice między wartościami poszczegól- 
nych pomiarów występują w zakresie strukturalizacji czasu przy wejściu do szkoły $F(3)=8,6, p<0,05$. Po przeanalizowaniu średnich rang można stwierdzić, że ta przestrzeń w dwóch początkowych momentach roku szkolnego charakteryzowała się częstszym strukturalizowaniem czasu w postaci form zmierzających ku wycofaniu $\left(\mathrm{M}_{\mathrm{rang}}=1,89, \mathrm{M}_{\mathrm{rang} 2}=1,89\right)$. Trzeci moment charakteryzuje się wysokim wskaźnikiem wykorzystywania form bliższym intymności $\left(\mathrm{M}_{\text {rang3 }}=3,33\right)$, którego wartość spada $\mathrm{z}$ końcem roku $\left(\mathrm{M}_{\mathrm{rang} 4}=2,89\right)$. Siła zgodności porównywanych średnich rang obliczona testem W-Kendalla jest słaba ( $\mathrm{W}=0,32, \mathrm{p}<0,05)$. Może to oznaczać, że pewne czynniki, uwidaczniające się w trzecim momencie roku szkolnego, mogą mieć duże znaczenie przy pojawieniu się form bliższych intymności przy wejściu do szkoły. Taką okolicznością mogły być zorganizowane dni otwarte szkół, które w metaforycznym sensie odnoszą się do otwarcia szkoły (jej drzwi) na nowe osoby. Dzięki temu przestrzeń przy wejściu do placówki mogła zostać niejako „oswojona” oraz spostrzegana jako nie tylko miejsce wejścia/ wyjścia ze szkoły.

Ostatnią wykonaną analizą w tym podrozdziale jest obliczenie współczynnika korelacji rho-Spearmana między wartościami poszczególnych form strukturalizacji czasu a miejscami, w których czas ten jest wykorzystywany w danej formie. Można stwierdzić, że wszystkie wykazane korelacje są bardzo słabe $\left(\rho_{\mathrm{s}}<0,30\right)$ i można je zinterpretować następująco: badani uczniowie, którzy cechowali się wysokim poziomem wycofania, nie będą raczej przejawiać tej formy w swoich zachowaniach z przodu budynku szkoły oraz w szatni. Respondenci przejawiający wysoki poziom rozrywek będą tak spędzać czas w szatni i sali gimnastycznej, natomiast wysoki poziom prac u uczniów rzadko wystąpi z przodu budynku, w czytelni i szatni oraz przy wejściu do szkoły. Licealiści, wykazujący się wysokim wskaźnikiem zabawy, będą częściej przejawiać te formę z przodu i z tyłu siedziby szkoły, w szatni, na schodach i korytarzu oraz w sali gimnastycznej. Osoby, charakteryzujące się wysokim poziomem gier, będą je częściej od innych wykorzystywać w toalecie, a rzadziej w sekretariacie. I w końcu wysoki wskaźnik intymności u licealistów może wskazywać na częstsze przejawianie tej formy z przodu szkoły, w szatni, na korytarzu i w sali gimnastycznej.

\section{WNIOSKI I DYSKUSJA}

Przeprowadzone badania pozwoliły sformułować kilka wniosków:

- intymność występuje głównie poza budynkiem szkoły, natomiast wycofanie jest charakterystyczne dla czytelni i toalety; 
- rytuały są formami spędzania czasu charakterystycznymi dla przestrzeni, gdzie spotykają się uczniowie i nauczyciele (klasa szkolna, biblioteka, wejście do szkoły);

- rozrywki zostały odnotowane w przestrzeniach, gdzie przeważnie przebywają tylko uczniowie (szatnia, przebieralnia, schody, korytarz), a zabawy występują głównie w sali gimnastycznej;

- prace występują głównie w miejscach przeznaczonych dla nauczyciela (pokój nauczycielski, sekretariat, gabinet dyrektora); w tych przestrzeniach notuje się także największy wskaźnik gier.

Można stwierdzić, że szkoła nie sprzyja realizacji zadania rozwojowego w ujęciu R. Havighursta, jakim jest osiągnięcie nowych i bardziej dojrzałych relacji $\mathrm{z}$ rówieśnikami obu płci. Związane jest to $\mathrm{z}$ brakiem intymności w szkole. Osiągnięcie tego zadania powoduje dobre przystosowanie społeczne, natomiast jego brak - problemy w relacjach z innymi ludźmi. Licealiści często mają opóźnienia w realizacji tego zadania, toteż szkoła musi stwarzać warunki do nabywania umiejętności społecznych poprzez np. stwarzanie warunków do strukturalizacji czasu w formie intymności. Częstsze wstępowanie tej formy może także wzmocnić autonomię uczniów i osłabić lęk, brak uczucia koherencji i ufności do świata wśród uczniów. Można to osiągnąć poprzez stworzenie przestrzeni przeznaczonej dla uczniów, w której mogliby oni usiąść i odpocząć w czasie między lekcjami, spokojnie porozmawiać z innymi uczniami, co sprzyjałoby spędzaniu czasu w formie intymności. Innym pomysłem jest przeprowadzenie kursu „Edukacji temporalnej”, opartej na programie GEM (ang. Goal-setting, Experiential, Motivational Program for High School Students), który jest intensywnym i krótkotrwałym kursem analizy transakcyjnej, adresowanym do uczniów szkół średnich, mający na celu podniesienie poziomu motywacji, frekwencji, autonomii i dyscypliny (Jagieła, 2012b, s. 75).

\section{BIBLIOGRAFIA}

Adam, B. (2010). Czas. Tłum. M. Dera. Warszawa: Wydawnictwo Sic!

BAŃKA, A. (2010). Typy tożsamości wczesnej dorostości z perspektywy orientacji czasowej preferowanych stylów życia, W: K. PopioŁeK, A. ChudzicKa-CzuPAŁA (red.), Czas w życiu człowieka (s. 101-116). Katowice: Wydawnictwo Uniwersytetu Śląskiego.

Berne, E. (2000). W co graja ludzie? Psychologia stosunków międzyludzkich. Tłum. P. Izdebski. Warszawa: Wydawnictwo Naukowe PWN.

Berne, E. (2008). Dzień dobry... i co dalej? Tłum. M. Karpiński. Poznań: Dom Wydawniczy REBIS. 
Clarke, A.E. (2003). Situational Analyses: Grounded Theory Mapping After the Postmodern Turn. Symbolic Interaction, 26(4), 553-576.

Clarke, A.E. (2005). Situational Analysis. Grounded Theory After the Postmodern Turn. Thousand Oaks, CA: Sage.

Cowles-Boyd, L., Boyd, H.S. (1980). Play as a Time Structure. Transactional Analysis Journal, 10(1), 5-7.

CZEREPANIAK-WALCZAK, M. (2009). Od próżniaczenia do zniewolenia - w poszukiwaniu dyskursów czasu wolnego, W: E. MARYNowicz-HeTKA (red.), Pedagogika spoteczna, (s. 219-236). Warszawa: Wydawnictwo Naukowe PWN.

Harris, T. (2009). Ja jestem OK - ty jesteś OK. Praktyczny przewodnik po analizie transakcyjnej. Tłum. E. Knoll. Poznań: Dom wydawniczy REBIS.

JAGIEŁA, J. (2001). Transactional analysis (TA) as a way of improving the interpersonal competence of teachers in the twenty - first century, W: A. KozŁowKSA, B. KožUH (red.), The quality of education in the light of educational challenges and tendencies of the third millennium (s. 35-42). Częstochowa: Wydawnictwo WSP.

JAGIEŁA, J. (2012a). Edukacyjna analiza transakcyjna $w$ kilku odstonach. Częstochowa: Wydawnictwo AJD.

JAGIEŁA, J. (2012b). Stownik analizy transakcyjnej. Częstochowa: Wydawnictwo AJD.

JAGIEeA, J., SARNAT-CIASTKO, A. (2015). Dlaczego analiza transakcyjna. Rozmowy o zastosowaniu analizy transakcyjnej w pracy nauczyciela $i$ wychowawcy. Częstochowa: Wydawnictwo AJD.

James, M., Jongeward, D. (1994). Narodzić się, by wygrać. Analiza transakcyjna na co dzień. Tłum. A. Suchańska. Poznań: Dom Wydawniczy REBIS.

KACPERCZYK, A. (2007). Badacz i jego poszukiwania w świetle „Analizy Sytuacyjnej” Adele E. Clarke. Przeglad Socjologii Jakościowej, 3(2), 5-32.

KAWECKI, I. (2003). Wprowadzenie do wiedzy o szkole i nauczaniu. Kraków: Impuls.

KorZenieCKA-Bondar, A. (2011). Czas na pozór... Studia Pedagogiczne, 64, 113-130.

KwiatKowsKa, H. (2001). Czas, miejsce, przestrzeń - zaniedbane kategorie pedagogiczne. W: A. Nalaskowski, K. Rubacha (red.), Pedagogika u progu trzeciego tysiaclecia. Materiaty pokonferencyjne (s. 61-72). Toruń: Wydawnictwo UMK.

KWIECIŃSKI, Z. (1979). Budżet czasu uczniów a ich środowisko. Warszawa: PWN.

KwIECIŃSKI, Z. (2014). Pedagogie postu. Preteksty - konteksty - podteksty. Kraków: Impuls.

MoKrZYCKA, A. (2015). Zabawa jako dodatkowa kategoria strukturalizacji czasu. Edukacyjna Analiza Transakcyjna, 4, 89-99.

Nalaskowski, A. (2002). Przestrzenie i miejsca szkoty. Kraków: Impuls.

PANKOWSKA, D. (2001). Nauczyciel w perspektywie analizy transakcyjnej. Lublin: Wydawnictwo UMCS.

PANKowsKA, D. (2012). Analiza transakcyjna w edukacji czy edukacyjna analiza transakcyjna? próba porządkowania znaczeń. Edukacyjna Analiza Transakcyjna, 1, 13-30.

PANKowsKa, D., SoKoŁowsKa-Dzioba, T. (2015). Skuteczna edukacja szkolna $w$ kontekście zadań nauczyciela-wychowawcy. Lublin: Wydawnictwo UMCS.

PAWEŁCZYŃsKa, A. (1986). Czas człowieka. Wrocław: Zakład Narodowy im. Ossolińskich.

PRÜFER, P. (2016). Linearne i cykliczne procesy formacyjno-socjalizacyjne w społeczeństwie i w środowisku akademickim a niepełnosprawność. W: B. SzCZuPaŁ, K. KutEK-SŁadeK (red.), 
Wielowymiarowość integracji społeczno-zawodowej studentów z niepetnosprawnościa (s. 137155). Kraków: Uniwersytet Papieski Jana Pawła II. Wydawnictwo Naukowe.

Przybysz, A. (2010). Czas w pedagogice. W: K. PopioŁek, A. Chudzicka-CzupaŁA (red.), Czas w życiu cztowieka (s. 150-159). Katowice: Wydawnictwo UŚ.

Rogoll, R. (1989). Aby być sobq. Wprowadzenie do analizy transakcyjnej. Tłum. A. Tomkiewicz. Warszawa: Państwowe Wydawnictwo Naukowe.

STANISZKIS, J. (2004). Władza globalizacji. Warszawa: Scholar.

SzTejnberG, A. (2007). Środowisko proksemiczne komunikacji edukacyjnej. Opole: Wydawnictwo UO.

Tarkowska, E. (1992). Czas w życiu Polaków. Wyniki badań, hipotezy, impresje. Warszawa: Polska Akademia Nauk, Instytut Filozofii i Socjologii.

TruszkowsKa-WojtKowiak, M. (2012). Fenomen czasu wolnego. Gdańsk: Harmonia Universalis.

WAWRZYNIAK-BESZTERDA, R. (2002). Doświadczenia komunikacyjne uczniów w czasie lekcji. Studium empiryczne. Kraków: Impuls.

\section{STRUKTURALIZACJA CZASU UCZNIÓW LICEUM W FIZYCZNEJ PRZESTRZENI SZKOŁY}

\section{STRESZCZENIE}

Artykuł wykorzystuje kategorię czasu do opisu rzeczywistości edukacyjnej. Kategoria ta ma wielki potencjał, który wydaje się nie być wykorzystywany przez pedagogów. Tekst charakteryzuje formy strukturalizacji czasu przejawiane przez uczniów liceum w poszczególnych fizycznych przestrzeniach szkoły. Podstawą badań byłą koncepcja analizy transakcyjnej, stworzona przez Erica Berne’a w połowie XX wieku. W badaniach wykorzystano technikę zwaną mapowaniem, która pozwoliła na określenie transakcyjno-temporalnego profilu poszczególnych przestrzeni szkolnych.

Słowa kluczowe: czas; przestrzeń; szkoła; analiza transakcyjna.

\section{TIME STRUCTURING OF HIGH SCHOOL STUDENTS IN THE PHYSICAL SPACE OF THE SCHOOL}

\section{SUMMARY}

The article uses the category of time to describe educational reality. This category has great potential, which seems not to be used by pedagogues. The text characterizes the forms of time structuring manifested by high school students in individual physical spaces of the school. The fundamental of the research was the concept of transactional analysis, created by Eric Berne in the mid-twentieth century. The research used a technique called mapping, which allowed to determine the transactional-temporal profiles of individual school spaces.

Key words: time; space; school; transactional analysis. 